\title{
POLÍTICOS MENTIROSOS Y TRAMPOSOS DEMOCRÁTICOS: ¿ES LA MENTIRA POLÍTICA DIFERENTE DE OTRAS CLASES DE MENTIRAS?
}

\author{
Juan Samuel Santos Castro* \\ doi: 10.11144/Javeriana.uph36-72.pmtd
}

\begin{abstract}
RESUMEN
En este artículo defiendo la idea de que existen diferencias relevantes entre la mentira común y la mentira política. Mi propósito es mostrar que las dificultades con la mentira política no tienen que ver solamente con cuestiones metafísicas o conceptuales acerca de la delimitación del ámbito de la política o del concepto de lo político, ni con la solidez de las excusas y justificaciones que se ofrecen en favor de los políticos mentirosos. Sostengo que la mentira política es una forma especial de mentira debido, primero, a la peculiaridad del uso del lenguaje en política y, segundo, a la función de las mentiras políticas, a saber, socavar diversas clases de condiciones epistémicas necesarias para la discusión imparcial de los desacuerdos sociales. En este trabajo dejo sin responder la pregunta de cuál sea la mejor forma de articular aquellas condiciones epistémicas en la discusión política democrática.
\end{abstract}

Palabras clave: mentira; política; discusión; persuasión; democracia

Pontificia Universidad Javeriana, Bogotá, Colombia.

Correo electrónico: juan.santos@javeriana.edu.co

Para citar este artículo: Santos Castro, J. S. (2019). Políticos mentirosos y tramposos democráticos: ¿es la mentira política diferente de otras clases de mentiras? Universitas Philosophica, 36(72), 17-52. ISSN 0120-5323, ISSN en línea 2346-2426. doi: 10.11144/Javeriana.uph36-72.pmtd

Este artículo es resultado del proyecto de investigación "Mentira, poder estatal y democracia”, financiado por la Vicerrectoría de Investigación de la Pontificia Universidad Javeriana - Bogotá, ID Propuesta: 07801, ID Proyecto: 08016. Para la elaboración de este trabajo me beneficié inmensamente de las discusiones con los miembros del grupo de estudio Mentira, poder estatal y democracia de la Facultad de Filosofía de la Pontificia Universidad Javeriana. Agradezco su interés, entusiasmo 


\title{
LYING POLITICIANS AND DEMOCRATIC CHEATERS: IS POLITICAL LYING DIFFERENT FROM OTHER KINDS OF LYING?
}

\begin{abstract}
In this article, I defend the idea that there are important differences between lying in politics and lying in general. My aim is to show that the issues with political lies do not have to do only with metaphysical or conceptual questions regarding what politics is or what the concept of the political means, or only with the validity of the excuses and justifications commonly offered in favor of political liars. I hold that the political lie is a special form of lie due, first, to the peculiarity of the use of language in politics, and second, to the function that political lies play in political discussions: they undermine several epistemic conditions needed to impartially discuss social disagreements. In this work, however, I leave unanswered the question of what might be the best way to account for the epistemic conditions of democratic political discussions.
\end{abstract}

Keywords: lying; politics; discussion; persuasion; democracy

y persistencia crítica, todas condiciones epistémicas necesarias para la vida intelectual. Debo un agradecimiento especial a Bernardo Caycedo, Óscar Piedrahita y Ángela Calvo por sus valiosos comentarios a versiones previas de este artículo. 


\section{Introducción}

Adoptar una ACTITUd RAzonable frente a la mentira en política es sorprendentemente difícil. Por un lado, la animadversión que producen ciertas figuras políticas puede provocar una percepción exagerada de la frecuencia con la que los políticos mienten y del reproche que merecen cuando lo hacen. Por otro lado, el rechazo que produce la imagen de que las decisiones políticas dependen de las escaramuzas entre agentes dedicados a perseguir su propio interés puede llevarnos a conceder que la moral no aplica a la política. El debate teórico contemporáneo sobre la mentira en política busca huir de ambos extremos. Una importante pregunta para la consideración filosófica de la mentira política es si esta constituye un fenómeno diferente al de la mentira común y corriente. Aunque muy raramente planteada, esta pregunta es imprescindible para escoger el mejor enfoque de investigación, pues, si no hay diferencias relevantes entre la naturaleza de la mentira común y la de la mentira política, las investigaciones éticas sobre aquella bastarían para comprender los aspectos más acuciantes de esta. Pero si las hay, es necesario caracterizar precisamente aquello que hace especial a la mentira política, considerar cuál es su estatus moral, cuál es el distintivo daño o perjuicio que produce y cuáles deben ser las reacciones morales y legales más adecuadas ${ }^{1}$.

En este trabajo defenderé la idea de que existen diferencias relevantes entre ambas clases de mentira. Mi propósito es mostrar que las dificultades con la mentira política no tienen que ver solamente con cuestiones conceptuales o metafísicas acerca de la delimitación del ámbito de la política o del concepto de lo

1 ¿Hay alguna distinción significativa entre la tesis de que la mentira política es diferente a la mentira común y la tesis de que la mentira política es un tipo o caso especial de la mentira común? A primera vista, la distinción entre estas dos tesis solo es de grado: decir que es diferente, y no un mero tipo o caso especial, significaría que entre la mentira política y la mentira común hay más rasgos distintivos que aquellos que habría si aquella solo fuera un caso especial de esta. Sin embargo, como debe ser obvio, ninguna de las dos tesis implica afirmar que la mentira política no cuenta como mentira. Quizás lo realmente importante es preguntarse si las diferencias que existen entre la mentira política y la mentira común (si es que existen) son lo suficientemente relevantes como para que los recursos que usamos para comprender el fenómeno de la mentira política y los criterios de evaluación moral que usamos cuando juzgamos posibles casos debieran ser otros que aquellos que usamos para comprender y evaluar la mentira común. En este trabajo argumentaré que sí lo son. Agradezco al evaluador anónimo que me llamó la atención sobre la necesidad de aclarar este punto. 
político (Jay, 2010), o con la solidez de las excusas y justificaciones morales que se ofrecen en favor de los políticos mentirosos (Ramsey, 2000). Mi sugerencia es que, antes de abordar tales preguntas, vale la pena reflexionar sobre la naturaleza propia de la mentira política. Para mostrar en qué consisten las diferencias entre la mentira política y otras clases de mentira, discutiré algunas definiciones contemporáneas de la mentira común y señalaré algunos rasgos de las mentiras políticas que las hacen peculiares, para, a continuación, indicar aquello que, a mi juicio, hace especial a la mentira política. Aunque mi definición de la mentira política admite mayor precisión, el argumento de este trabajo es suficiente para plantear la tesis de que la mentira política se caracteriza porque su función es socavar diversas clases de condiciones epistémicas necesarias para la discusión imparcial de desacuerdos sociales. En las dos últimas secciones, mencionaré algunas consecuencias de mi propuesta y las preguntas que esta deja abiertas.

\section{La definición tradicional de la mentira}

Mi DISCUSIÓN EN ESTE TRABAJO parte del supuesto de que reflexionar sobre la naturaleza de la mentira es útil, si queremos ser capaces de explicar por qué consideramos moralmente reprochables los actos de habla que llamamos de esa manera. Precisar qué sea la mentira (y, en particular, la mentira política) facilitaría la reflexión sobre la clase de juicio moral que se amerita en casos concretos, permitiría articular más claramente nuestras actitudes hacia la veracidad y el engaño y, eventualmente, motivaría la reforma de tales juicios y actitudes si llegaran a parecer incoherentes o injustificados (Bok, 2010). Thomas Carson (2010) expresa concisamente el razonamiento subyacente al afirmar:

las cuestiones conceptuales acerca de la naturaleza de la mentira y el engaño son anteriores a las cuestiones sobre el estatus moral de mentir y engañar porque el que la mentira y el engaño sean moralmente incorrectos o no, depende de qué sean la mentira y el engaño (p. 13; traducción propia $)^{2}$.

2 "conceptual questions about the nature of lying and deception are prior to questions about the moral status of lying and deception because whether or not lying/deception is wrong depends on what lying/ deception is." 
Las definiciones disponibles en la literatura especializada sobre la mentira son numerosas (Mahon, 2016). La mayoría de ellas son variantes de la "definición tradicional de mentir", como la llama Mahon (2016), la cual consiste en cuatro condiciones, conjuntamente necesarias, para calificar un determinado acto de habla como una mentira:

primero, mentir requiere que una persona haga un enunciado (la condición del enunciado). Segundo, mentir requiere que la persona [que miente] crea que el enunciado es falso (la condición de no-verdad). Tercero, mentir requiere que haya otra persona a la que se le dirija el enunciado no verdadero (la condición del receptor). Cuarto, mentir requiere que la persona [que miente] tenga la intención de que la otra persona crea el enunciado no verdadero como verdadero (la condición de la intención de engañar al receptor) (s. p.; traducción propia) $)^{3}$.

De acuerdo con esta definición, hay dos características de la mentira que la distinguen del engaño. Primero, mientras que el término "engaño" se refiere a cualquier método (lingüístico o no) para hacer que otro crea algo que el que engaña no cree, la mentira es aquella forma de engaño que se produce mediante el lenguaje articulado, ya fuere este oral, escrito o simbólico. La definición tradicional busca capturar este rasgo de la mentira mediante la "condición del enunciado"

Segundo, mentir es un verbo de conducta, mientras que engañar es verbo de resultado. Esto significa que, para mentir, basta con que el hablante dirija el enunciado falso a otra persona o personas, mientras que, para engañar, es necesario que, además del despliegue de la maniobra engañosa, la víctima resulte efectivamente engañada. En la definición tradicional, este rasgo de la mentira es capturado conjuntamente por las condiciones del enunciado y del receptor y,

"First, lying requires that a person make a statement (statement condition). Second, lying requires that the person believe the statement to be false; that is, lying requires that the statement be untruthful (untruthfulness condition). Third, lying requires that the untruthful statement be made to another person (addressee condition). Fourth, lying requires that the person intend that that other person believe the untruthful statement to be true (intention to deceive the addressee condition)".

4 Sissela Bok enfatiza expresamente esta característica, al definir la mentira como todo "mensaje intencionalmente engañoso en la forma de un enunciado” (Bok, 2010, p. 45. Énfasis en el original). 
especialmente, por la ausencia de una condición que sujete la configuración de la mentira a su éxito.

En este trabajo asumiré que la mentira política es una clase de mentira, esto es, que constituye una forma especial de engaño en los dos sentidos explicados en el párrafo anterior. No obstante, sostendré que la mentira política es además una forma especial de mentira debido, primero, a la peculiaridad del uso del lenguaje en política y, segundo, a la función que cumple el despliegue de las mentiras políticas. En la siguiente sección, discutiré la manera en que una caracterización de la mentira política podría beneficiarse de un par de correcciones a la definición tradicional de la mentira, con el fin de iniciar mi argumento cuestionando la plausibilidad de la cuarta condición aplicada a la mentira política. En efecto, la intención de engañar es insuficiente para distinguir qué cuenta como mentira en política. En la sección siguiente explicaré por qué, llamando la atención sobre los usos del lenguaje en la política, y sugeriré en qué podrían consistir las condiciones distintivas de la mentira política.

\section{La mentira y las intenciones de los políticos}

LA DEFINICIÓN TRADICIONAL DE LA MENTIRA tiene la ventaja de ser simple e intuitiva. Quizás por ello, la mayoría de autores interesados en el tema la adoptan como correcta, sin preguntarse con cuidado si en realidad sirve para comprender adecuadamente los problemas de la mentira en políticas. Sin embargo, no es

5 Por mencionar algunos ejemplos: Arendt (1967/2017a; 1971/2017b) no cuestiona abiertamente la definición tradicional, pero parece aceptarla solo a medias. Para ella, la mentira política es aquella falsedad deliberada que atañe a los hechos contingentes o a lo que ella llama "verdades de hecho". Por su parte, y aunque con la precaución usual en un científico social, Barnes (1994, pp. 10, 30) acoge la definición tradicional y la aplica sin notar problemas específicos al ámbito de la política. Bok (2010) define la mentira como todo "mensaje intencionalmente engañoso en la forma de un enunciado" (p. 45) y la usa para explorar la moralidad de mentir en diferentes clases de circunstancias, algunas claramente políticas. Jay (2010, p. 130) revisa numerosas concepciones de la mentira, sin adoptar una en particular y sin notar diferencias entre la mentira común y la política, pues parte de su propósito es mostrar que lo que cuente como mentira o engaño y cómo se valore depende de la concepción de lo político que cada autor defienda. Finalmente, es también la definición que recogen Tullock (1967), Ekman (1992/2005), Stanley (2012) y Fallis y Mathiesen (2017), en sus análisis sobre el fenómeno de la mentira política, y Oborne (2005) y Ramsey (2000) en sus discusiones sobre la moralidad de la mentira en política. 
difícil notar que algunas de las correcciones propuestas para la definición tradicional de la mentira común son especialmente pertinentes para la mentira política. Hay dos que son relevantes para mis propósitos.

Por un lado, Chisholm y Feehan (1977) advierten que aquello sobre lo que el mentiroso quiere engañar a su interlocutor no necesariamente es el contenido del enunciado que hace, sino más frecuentemente sus creencias sobre el contenido del enunciado que hace. Esta observación puede extenderse para dar cuenta de ciertas mentiras en política. Por ejemplo, supongamos que Andrés actuó incorrectamente y que Álvaro lo sabe. Si Álvaro afirma: "Andrés nunca hizo nada incorrecto", Álvaro puede querer, o bien hacernos creer que Andrés no actuó incorrectamente, o bien hacernos creer que él, Álvaro, no cree que Andrés haya actuado incorrectamente. Incluso, puede hacernos creer que Andrés no hizo nada incorrecto y además que él, Álvaro, no cree que Andrés haya hecho nada incorrecto. En casos diferentes, puede ser crucial si el hablante miente sobre el contenido del enunciado, o sobre sus creencias acerca del contenido del enunciado, o sobre ambos. Si interviene en una entrevista televisiva, lo más efectivo sería hacernos creer en la verdad de ambos, pero si rinde testimonio frente a un juez, sería conveniente para él comprometerse solamente con el enunciado sobre sus creencias acerca del contenido, y no con la verdad del contenido mismo.

Por otro lado, que la intención de engañar (la cuarta condición) sea necesaria para mentir es un punto de álgida controversia actual entre quienes debaten sobre la definición de mentira ${ }^{6}$. A favor de la condición está que la intención de engañar parece ser el elemento más intuitivo del concepto de mentira, pues no solamente marca su parentesco con el engaño (Chisholm \& Feehan, 1977) 7 , sino que parece explicar el reproche moral que se atribuye al mentiroso (Coleman \&

6 La intención de engañar es un elemento tan central en las discusiones contemporáneas sobre la mentira que, en su instructiva reconstrucción del debate, Mahon (2016) divide el campo entre lo que él llama "deceptionists" y "non-deceptionists".

7 Chisholm y Feehan (1977, pp. 143-144) distinguen ocho formas de engaño de acuerdo con los criterios de si el engaño ocurre por comisión o por omisión y de si se trata de engaños "simpliciter" (quien engaña provoca el engaño) o "secumdum quid" (quien engaña evita que el otro deje de estar engañado). Chisholm y Feehan entienden que la intención de engañar es precisamente lo que define a todas estas como formas de engaño. La mentira, en estricto sentido, sería aquella forma de engaño simpliciter que se hace mediante aseveraciones (assertions). 
Kay, 1981; Hardin, 2010) ${ }^{8}$. En contra, varios autores (Carson, 2010; Fallis, 2009; Meibauer, 2014, Saul, 2012; Sorensen, 2007) señalan que una definición que incluya tal elemento como condición necesaria no puede cubrir casos de mentiras para el registro ("on record") y de mentiras descaradas ("bald-faced lies")'.

Para mostrar que la condición de la intención de engañar excluye las mentiras para el registro (on record), Carson propone imaginar al testigo de un crimen que puede identificar claramente al culpable y es llamado a testificar en un proceso judicial. Su testimonio ayudará a la condena, pero no es la única prueba; de hecho, incluso prescindiendo de su testimonio, la evidencia en contra del culpable es abrumadora. El testigo es consciente de este hecho, y también de que, si atestigua verazmente, la banda criminal de la que el culpable hace parte se vengará de él. En estas circunstancias, cuando el juez lo interroga, el testigo niega saber quién cometió el crimen, contando con que ni el juez ni el jurado serán engañados, dado el resto de la evidencia, y que el culpable será condenado con base en esta. En este caso, según Carson (2010, p. 20), el testigo miente, aunque no tiene la intención de engañar. En otro ejemplo, también propuesto por Carson, el decano de cierta facultad instituye la política de no sancionar a ningún estudiante acusado de fraude académico, a menos que este confiese explícita y voluntariamente. Esta política busca evitar las demandas legales de estudiantes sancionados con base en otra clase de pruebas. Posteriormente, cierto estudiante es atrapado cometiendo fraude de forma evidente en un examen. Pero el estudiante conoce la nueva política instituida por el decano, así que, cuando este le pregunta si cometió fraude, el estudiante lo niega, a sabiendas de que no logrará engañar a su

8 Mediante análisis de prototipo semántico, estos autores encuentran que la intención de engañar es clave para distinguir a qué se llama “lie” (Coleman \& Kay, 1981) y a qué mentira (Hardin, 2010), de un lado, y a qué expresión de cortesía, desorientación o error, del otro.

9 Nótese que afirmar que es posible mentir sin tener la intención de engañar no equivale a afirmar que sea posible mentir sin ninguna intención. Mentir sin intención (esto es, por negligencia o imprudencia) es imposible, pues cuando alguien hace una afirmación sin percatarse de que es falsa o equivocada, lo que decimos es que esa persona se equivocó y no que mintió, incluso si como resultado de la falsa afirmación alguien resulta confundido. Ahora bien, hay ocasiones en que es reprochable transmitir información falsa por equivocación (por ejemplo, cuando quien se equivoca tiene el deber de informarse bien y no lo hace), pero el reproche en estos casos se debe a que el que se equivoca viola un deber epistémico, no a que haya mentido. 
interrogador, pero esperando aprovecharse de la política que este ha establecido. En este caso, el estudiante también miente, aunque tampoco tiene la intención de engañar (Carson, 2010, p. 21).

Es probable que las mentiras para el registro (on record) sean tan frecuentes en política como en la vida cotidiana. Sin embargo, hay dos situaciones en las que los políticos se ven usualmente envueltos y que constituyen tentaciones recurrentes para que mientan para el registro (on record). La primera es la entrevista o intervención en un medio de comunicación masivo, la segunda los interrogatorios semijudiciales de control político. No es inusual que, cuando un político se enfrenta a una pregunta directa sobre su responsabilidad o su conocimiento de un determinado hecho, responda con enunciados que sabe falsos, aunque sepa que con ellos no logrará persuadir a su audiencia. Fue así como algunas personas percibieron la afirmación de Juan Manuel Santos, "el tal paro nacional agrario no existe" 10 , o la de Ernesto Samper, "todo sucedió a mis espaldas". En estos casos, así como en el del testigo o el del estudiante en los ejemplos de Carson, es probable que la motivación de los políticos sea que su respuesta mendaz quede registrada (on record), o que la veraz no lo haga, y no engañar con ella a nadie. Se trataría entonces, como sostiene Carson, de mentiras que no son provocadas por la intención de engañar.

10 Véase, por ejemplo, la caricatura que acompañó al artículo de la revista Semana titulado "Santos: 'el tal paro nacional agrario no existe”" (2013). Ciertamente, es posible entender la afirmación de Santos como una forma de señalar la ilegitimidad de la violencia como medio de protesta (o de control de la protesta), o la ilegitimidad de la instrumentalización de la protesta para fines partidistas. La mayoría de los reportes periodísticos resaltaban ese sentido, cuando tomaban en conjunto las afirmaciones del presidente. Sin embargo, como se puede inferir a partir de la redacción de las noticias en las que se reportó la afirmación, la expresión sugería una suerte de sospechosa "miopía" (como se lee en la leyenda de la caricatura) de parte del presidente. Quizás, la expresión fue simplemente desafortunada y confusa. La revista Dinero reportó la noticia así: "la huelga del sector agropecuario en Colombia, que cumple una semana, deja cuatro muertos, 160 policías y un número indeterminado de manifestantes heridos y el bloqueo de vías, pese a lo cual el presidente Juan Manuel Santos restó hoy importancia al movimiento de protesta señalando que 'no existe”. Más adelante, Santos intentó aclarar el sentido de su afirmación diciendo que lo que negó fue el alcance nacional del paro, no la existencia misma de las protestas: "cuando digo que el paro no es nacional es porque está concentrado en unos pocos departamentos y en unos productos determinados" ("El tal paro nacional agrario no existe", 2013). 
En las mentiras descaradas ("bald-faced lies") tampoco parece haber intención de engañar. Para ilustrar esta clase de mentiras, Sorensen (2007) describe un hecho que ocurrió durante la guerra de Irak en el 2003. La periodista noruega Asne Seierstad ingresó a un hospital civil en una ciudad iraquí y se sorprendió de verlo ocupado por soldados iraquíes heridos. Dado que tal hecho podía implicar que las fuerzas locales estaban a la defensiva, Seierstad preguntó a un médico por el número de soldados admitidos. El médico respondió: "aquí no hay soldados" y cuando la periodista le hizo notar que los pacientes vestían uniformes, el médico insistió: "yo no veo ningún uniforme". Las mentiras descaradas difieren de las mentiras on record en dos aspectos. Primero, la falsedad de la mentira descarada es absolutamente evidente y, por tanto, no cabe ninguna duda de que la intención de quien miente no es engañar a nadie. Segundo, la mentira descarada no es necesariamente defensiva, como lo es la del testigo y el estudiante en los ejemplos de Carson o en el de los políticos que buscan evadir su responsabilidad. De allí que tampoco sean mentiras motivadas por la necesidad de que queden registradas. Meibauer (2014) sostiene por ello que las mentiras descaradas constituyen en realidad usos ofensivos del lenguaje: cuando se miente descaradamente se busca insultar al interlocutor, más que engañarlo.

Dos ejemplos recientes en política ilustran esta idea. Justo después de que el Colegio Electoral de Estados Unidos declarara su victoria, Donald Trump afirmó que la suya había sido la votación popular más numerosa desde Reagan. El enunciado era patentemente falso, lo que cualquiera que siguiera esporádicamente las noticias, o que tuviera acceso a un texto de historia, podía verificar. Sin embargo, la mentira parecía tener como objetivo agredir a Hillary Clinton, aprovechando que la votación que ella obtuvo sí fue cercana a la de Reagan. No mucho después, en febrero de 2016, justo después de tomar posesión de la presidencia, Trump afirmó que recibía al país con la tasa de homicidios más alta en 47 años. Sin embargo, el Reporte unificado sobre el crimen, elaborado por el FBI y publicado poco antes, sostenía que en el 2015 se había alcanzado la tasa más baja de homicidios en la historia registrada. La ofensa esta vez iba dirigida a su predecesor en el cargo ${ }^{11}$.

11 Tomo ambos ejemplos de McIntyre (2018, p. 2), donde pueden consultarse las fuentes primarias de ambos episodios. Lo ofensivo en las mentiras descaradas no se explica siempre de la misma forma. 
No es inusual entonces que los políticos mientan sobre sus creencias acerca de los hechos de los que hablan o que mientan sin la intención de engañar. Hay dos consecuencias que se siguen de esta discusión: primero, la definición tradicional no parece capturar las mentiras en las que la falsedad no está en lo que el enunciado dice literalmente (recuérdese el caso de Álvaro y Andrés). Segundo, la definición tradicional tampoco parece capturar las mentiras en las que el objetivo principal no es que el interlocutor crea que lo que se dice es verdadero (Santos, Samper, Trump). Ya que en política se dan a menudo estas dos clases de mentira, la definición tradicional no es completamente adecuada para capturar lo específico de la mentira política. Ante tal deficiencia, las alternativas podrían ser, o bien ofrecer una definición general de la mentira que cubra esos casos, o bien plantear una definición de mentira política que atienda a su especificidad. La primera alternativa ha sido probada sin éxito hasta el momento (Mahon, 2016), así que, en vez de sumar otro intento de reforma a la definición tradicional, optaré por la segunda.

\section{La mentira y el lenguaje de la política}

\section{Considérese la siguiente definición de Carson (2010):}

L5. Una persona $S$ dice una mentira a otra persona $S 1$ si y solo si: 1) $S$ hace un enunciado $X$ a $S 1,2) S$ cree que $X$ es falso o probablemente falso (o alternativamente, $S$ no cree que $X$ sea verdadero), 3) $S$ enuncia $X$ en un contexto en el cual $S$ le garantiza [warrants] la verdad de X a S1, y 4) S no se toma a sí misma como si no estuviera garantizando [warranting] la verdad de aquello que dice a $S 1$ (p. 39; traducción propia) ${ }^{12}$.

Algunas de tales mentiras son ofensivas porque reflejan el cinismo del mentiroso; otras, porque delatan el desprecio del mentiroso por ciertas fuentes de información o por ciertas personas; otras, porque buscan exhibir el hecho de que el mentiroso puede mentir sin sufrir ninguna consecuencia; otras, quizás, porque hacen mofa de los personajes a los que se dirigen. La idea relevante para mis propósitos es que, independientemente de cómo funcione la agresión en cada caso, hay enunciados falsos que se dicen con la intención de agredir u ofender a los interlocutores, y no de engañarlos.

12 “L5'. A person $S$ tells a lie to a person S1 if: 1. S makes a statement X to S1, 2. S believes that X is false or probably false (or, alternatively, $S$ does not believe that $X$ is true), 3. $S$ states $X$ in a context in which $S$ thereby warrants the truth of $X$ to $S 1$, and 4 . S does not take herself to be not warranting the truth of what she says to $S 1$ ". 
Esta definición toma en cuenta los problemas planteados en la sección anterior. Por un lado, el concepto de garantizar la verdad del enunciado permite incluir los casos de las mentiras para el registro (on record) y de las mentiras descaradas, pues lo que se hace cuando se miente es romper una convención en vigor en contra de la expresión de enunciados falsos, la cual opera independientemente de las intenciones o probabilidades del engaño (Carson, 2010, pp. 20-24) ${ }^{13}$. Por otro lado, cuando el mentiroso traiciona la confianza de su audiencia, puede hacerlo, o bien porque ofrece un contenido que cree falso, o bien porque hace creer a su audiencia que el valor veritativo que él le atribuye al contenido del enunciado que hace es diferente al que realmente le atribuye.

Sin embargo, la definición de Carson y, como mostraré ahora, una gran cantidad de definiciones sobre la mentira común, son insuficientes para capturar lo que es peculiar a la mentira política. Para empezar, usualmente las definiciones de la mentira común dejan por fuera dos grandes grupos de actos de habla de los políticos por los que usualmente son acusados de mentir: i) la mentira por desorientación y falsa presuposición y ii) la mentira por ironía y lenguaje figurado o "en código".

i) Mentira por desorientación y falsa presuposición: Las definiciones comunes excluyen aquellos enunciados que el mentiroso considera estrictamente verdaderos, o al menos que no considera falsos, pero que expresa buscando que su audiencia infiera afirmaciones que son, o que él cree, falsas. Quienes recurren a esta clase de enunciados mentirían porque deliberadamente inducen a error a su audiencia, ya fuere desorientándola mediante alguna implicatura conversacional (Meibauer, 2005; Saul, 2012), o ya sea sugiriendo una falsa presuposición (Meibauer, 2014). No es sorprendente que los políticos mientan de estas formas, pues como anota Meibauer (2011, p. 283), así dejan abierta la posibilidad de evadir acusaciones con la excusa del malentendido.

13 Mentir, según Carson (2010), es “invitar a otros a confiar y apoyarse en lo que uno dice mediante la promesa de garantizar la verdad de lo dicho y, al mismo tiempo, traicionar tal confianza mediante la expresión de un enunciado falso que uno no cree verdadero" (p. 15; traducción propia). ["To lie is [...] to invite others to trust and rely on what one says by warranting its truth and, at the same time, to betray that trust by making a false statement that one does not believe to be truth".] 
Uno de los ejemplos más famosos de desorientación en la literatura especializada implica a un político ${ }^{14}$. Se trata de la respuesta que supuestamente ofreció Bill Clinton a la pregunta de un juez sobre si había tenido relaciones impropias con Monica Lewinsky. Clinton habría respondido: "No hay relación impropia alguna" ("There is no improper relationship"). El enunciado era estrictamente verdadero, pues expresado en tiempo presente, se refería al hecho de que en el momento en que Clinton respondía, no mantenía ninguna relación impropia con Lewinsky. Pero, dado que el contexto de la pregunta sugería que lo que se le pedía a Clinton era que dijera si alguna vez había tenido relaciones de esa clase con Lewinsky, la respuesta obligaba a inferir a la audiencia que Clinton negaba cualquier relación con Lewinsky en cualquier tiempo. Dado que Clinton, al parecer, sí mantuvo una relación impropia con Lewinsky mientras ella era su pasante en la Casa Blanca, aquel habría mentido induciendo a error a su audiencia.

Irónicamente, ni la pregunta ni la respuesta sucedieron como cuenta esta anécdota. Pero un suceso real, que de nuevo involucra a Clinton, sirve como ejemplo adicional (Green, 2006, pp. 140-147; Saul, 2012, p. 121). Durante el juicio que se adelantaba en su contra por acoso sexual a Paula Jones, Clinton tuvo que responder a la pregunta de si había tenido relaciones sexuales con Lewinsky. Él lo negó. La definición de relaciones sexuales que había sido admitida durante este litigio por el juez implicaba que no incurría en tales relaciones quien recibía sexo oral, pero sí quien lo administraba, de modo que al negar que hubiera mantenido relaciones sexuales con Lewinsky, bajo esa definición, Clinton estrictamente decía la verdad. Pero dado que se trataba de una definición tan peculiar, gran parte de la audiencia entendió que mentía al negarlo.

14 ¿Es el hecho de que la mentira sea dicha por un político suficiente para considerarla como una mentira política? A primera vista, la respuesta debería ser negativa. Los políticos no actúan como políticos todo el tiempo. Pero, quizás, lo importante no es tanto si la mentira es dicha por un político o si atañe o no solamente a sus actos como político, sino si la dice en un contexto político. En el caso que presento a continuación en el texto, aunque el hecho en cuestión pertenecía a la vida privada de Clinton, su investigación sería usada para probar la integridad moral del presidente estadounidense ante la nación, lo cual convertiría sus declaraciones en declaraciones políticas (Fallis \& Mathiesen, 2017). Más adelante, afirmaré algo un tanto diferente: lo relevante para determinar la naturaleza política de una afirmación es que haga parte de una discusión sobre asuntos públicos. 
Otro par de ejemplos muestran la relevancia y frecuencia en política de la mentira por falsa presuposición. Durante su campaña a la presidencia de Colombia, Iván Duque asistió, junto con otros candidatos, a un debate público sobre la corrupción ${ }^{15}$. Durante sus presentaciones, cada candidato debía explicar su definición de corrupción. Todos coincidieron en que sus nociones de corrupción incluían los casos usuales en la literatura especializada (Gardiner, 2007), casos en los que el corrupto es un funcionario público: desviación de recursos públicos para provecho particular, abuso de la calidad de servidor público, tráfico de influencias y de información privilegiada, etc. Todos coincidieron, además, en que la corrupción es moralmente reprochable. Cuando el debate estaba a punto de terminar, Duque afirmó que, según él, existía otro ejemplo de corrupción, no mencionado por nadie hasta ese momento, y que le sorprendía que solo él lo considerara condenable: el reclutamiento de menores para la guerra. El reclutamiento de menores no es técnicamente considerado como ejemplo de corrupción política, pero esperando que la imprecisión fuera pasada por alto, Duque intentó provocar la falsa presuposición de que los otros candidatos no consideraban tal acción como condenable.

El otro ejemplo de falsa presuposición en política es la táctica del pushpolling (Saul, 2012, pp. vii-viii). Esta táctica consiste en que, durante el periodo de campaña electoral, una compañía que supuestamente adelanta una encuesta de intención de voto hace llamadas a electores estadísticamente indecisos. Tanto la compañía como la encuesta son ficticias, pero las preguntas están diseñadas para hacer que los electores infieran información falsa que puede perjudicar a determinados candidatos. En las elecciones de las primarias del partido republicano del año 2000, la táctica fue desplegada contra John McCain. Los electores recibían preguntas como “¿Estaría usted más o menos dispuesto a votar por el senador McCain si supiera que es el padre ilegítimo de un niño de color?”. Quien realiza la encuesta no hace una afirmación falsa. De hecho, no hace una afirmación, sino una pregunta. Pero esta contiene una presuposición que puede ser inferida por los receptores de las llamadas como verdadera y así puede afectar sus decisiones de voto.

15 Conferencia Académica Inaugural 2018. Ética de lo público: responsabilidad de todos, organizada por la Universidad del Rosario, el 13 de febrero de 2018. 
ii) Mentira por ironía y lenguaje figurado o "en código": Otra clase de enunciados que las definiciones en cuestión no cubren son las expresiones irónicas. En este tipo de casos, el hablante miente, a pesar de que no lo hace mediante afirmaciones contrarias a lo que cree verdadero. La idea de que también se miente mediante ironía es defendida por David Simpson (1992), quien la ilustra mediante el siguiente ejemplo. Hay un hombre que sabe que hay ladrones en el camino. Cuando otro le pregunta si los hay, él responde que efectivamente los hay, pero exhibiendo signos de ironía (Simpson, 1992, p. 629). El otro individuo capta esos signos e infiere que no hay ladrones en el camino. Suponiendo que los signos irónicos no fueron accidentales, parece correcto decir que aquel hombre mintió. Una ventaja interesante de esta forma de mentira es que deja abierta la posibilidad de que el mentiroso evada su responsabilidad de una forma más efectiva que mediante la mentira por desorientación o por falsa presuposición, pues la defensa del mentiroso irónico sería que, en efecto, dijo literalmente la verdad.

¿Se miente de esta forma en política? Considérese el siguiente pasaje de Alexandre Koyré:

Es verdad que Hitler (como los otros caudillos de estados totalitarios), anunció todo su programa de acción públicamente. Pero porque sabía que sus declaraciones no serían tomadas en serio por los no iniciados, precisamente así, diciéndoles la verdad, estaba seguro de engañar a sus adversarios (Koyré, 1945, p. 296).

El comentario de Koyré es relevante para comprender la mentira en políti$\mathrm{ca}^{16}$. Un rasgo llamativo de la mentira mediante ironía es que permite al mentiroso engañar solo a una parte de la audiencia, mientras que, al tiempo y mediante el mismo enunciado, reafirma la confianza de otra. En efecto, en casos típicos de ironía, se pretende que la audiencia comprenda exactamente lo contrario de aquello que literalmente se dice ${ }^{17}$. Pero como sugieren Szabados y Soifer

16 Podría pensarse que Koyré se confunde, pues anunciar acciones futuras, sobre cuya ocurrencia nadie puede atribuirse conocimiento, no es exactamente igual que mentir sobre hechos pasados o presentes. Sin embargo, todo anuncio de acciones futuras implica la afirmación de intenciones presentes y, al menos en este sentido, Hitler habría mentido, en cierto sentido, por ironía.

17 Por ello, no es irrazonable excluir la ironía de la definición de la mentira común, como por ejemplo hace Saul (2012, p. 18). 
(2004, p. 292), no es inconcebible una situación en la cual quien despliega una ironía quiera dirigirse al mismo tiempo a dos públicos diferentes: uno, al que quiere transmitir el sentido pretendido, y otro, al que quiere que tal sentido se le escape. Szabados y Soifer explican que esto es posible cuando el ironista quiere divertirse con una parte del público a costa de la otra. Pero, en política, es quizás más parecido a lo que, en el contexto del pasaje citado, Koyré llama "conspiraciones a plena luz del día” (1945, p. 296). Koyré se refiere al comportamiento que adoptan los miembros de grupos políticos en condiciones extremadamente polarizadas de pugna por el poder, pero antes de llegar al enfrentamiento violento. En condiciones tales, cuando todavía sobreviven los formalismos de la rivalidad política normal, los partidos en disputa tienden a desarrollar lenguajes codificados que les permiten comunicar sus creencias, ideas y estrategias mediante los discursos públicos propios del proceso político corriente, sin despertar sospechas en sus contrincantes o, incluso, confundiéndolos ${ }^{18}$.

El uso de lenguaje codificado (dogwhistle) ilustra un rasgo común en el lenguaje al que se recurre en las pugnas por el poder político: hay expresiones, palabras clave, denominaciones cargadas, líneas de argumentos, tópicos y tropos que en boca de los políticos no buscan comunicar o engañar sobre aquello que estrictamente significan. Tomados literalmente, son falsos. Sin embargo, su objetivo consiste más bien en expresar la alianza con un conjunto de valores o modos de pensar (p. ej., "justicia sin impunidad", “nasty woman"), alertar disimuladamente sobre situaciones que se consideran peligrosas o indeseables para el grupo, clase o partido (p. ej., "la ideología de género del acuerdo de paz") o sugerir modos específicos de reacción contra grupos o individuos rivales concretos (p. ej., "the basket of undesirables", "los fascistas paramilitares" ${ }^{19}$ ). Estas formas de lenguaje

18 Atendiendo a un fenómeno parecido, pero en el caso específico del partido nacional-socialista, Arendt (1973/2006, p. 476) describe la forma en que el conocimiento gradual del lenguaje codificado del partido marcaba la diferencia entre quienes debían ser objetivos de propaganda política, de adoctrinamiento y lenguaje eufemístico, o de discurso político sincero.

19 "Justicia sin impunidad" era la expresión que recogía una de las críticas de aquellos que estaban en contra de que el gobierno del presidente colombiano Juan Manuel Santos firmara el acuerdo de paz con la guerrilla de las FARC. Según esta crítica, el acuerdo concedía demasiadas ventajas jurídicas a excombatientes de la guerrilla que hubieran cometido crímenes de cualquier clase durante el conflicto armado. "Nasty woman" fue una de las expresiones con las que Donald Trump describió a su 
disimulado constituyen en realidad una herramienta corriente de estrategia política y una que hace parte del arsenal usual, no solamente del totalitarismo, sino de los gobiernos y la oposición de los regímenes democráticos ${ }^{20}$.

La anterior discusión sugiere que no es sensato limitar el concepto de mentira política al tipo de casos en que los actores políticos comunican afirmaciones falsas mediante enunciados directos, pues ello equivale a coartar las posibilidades descriptivas y críticas del concepto. Y esto es así porque el lenguaje político no es siempre directo o literal; no se parece al lenguaje que esperaríamos en un tratado científico o en uno de filosofía analítica. Las formas de la mentira política son variadas, porque los políticos aprovechan los recursos de un lenguaje que no tiene el propósito principal de comunicar literalmente lo que se dice. De hecho, los géneros del discurso político son numerosos: la arenga preelectoral, la propaganda, el discurso de posesión o toma del poder, las alocuciones públicas de ataque o defensa de políticas o de individuos, los informes periódicos frente a la nación, los mensajes públicos en fechas conmemorativas, los testimonios autobiográficos o de memoria histórica, las declaraciones espontáneas en medios de comunicación masiva, y recientemente, los mensajes en redes sociales. Más aún, hay fines políticos legítimos para los cuales el lenguaje literal y veraz sería un obstáculo: los mensajes de aliento a las tropas en tiempos de guerra, o a la nación en general en tiempos de crisis. El lenguaje de la política cumple importantes funciones

rival Hillary Clinton durante la campaña electoral estadounidense de 2016. La expresión sugiere que se trata de una clase de mujer que merece un especial desprecio porque no cumple con ciertas expectativas de sumisión y amabilidad. "La ideología de género del acuerdo de paz" fue una expresión que usaron quienes se oponían al acuerdo de paz entre el gobierno colombiano y la guerrilla de las FARC y que jugaba con una que se repetía en el texto del acuerdo "enfoque de género". La variante de "ideología" pretendía transmitir la idea de que en los acuerdos, las partes trababan de introducir subrepticiamente privilegios o ventajas ilegítimas para las mujeres o para las personas LGBTI. "The basket of undesirables" fue la forma en que Hillary Clinton se refirió a varios de los políticos que apoyaban las políticas del entonces recién electo presidente estadounidense Donald Trump. La expresión pretendía transmitir la imagen de un conjunto de personas con creencias y actitudes homogéneas condenables moralmente. "Los fascistas paramilitares" es una expresión informal que busca describir, no sin cierta exageración, la posición política del segmento de derecha de la política colombiana.

20 Un aspecto interesante de esta clase de enunciados es que buscan objetivos perlocucionarios o ilocucionarios (expresar la alianza, alertar, prescribir modos de acción) mediante enunciados cuyo aparente objetivo ilocucionario es asertórico. 
ilocucionarias y perlocucionarias, muchas de ellas asociadas al objetivo de crear o expresar la cohesión, invitar a la alianza, la simple aquiescencia en torno a estrategias, valores o ideales o, lo contrario, a rechazar alianzas y destruir consensos.

Si unimos estas consideraciones a la discusión de la sección anterior, resulta cada vez menos plausible identificar lo característico de la mentira común con lo característico de la mentira política. Mientras que la desviación intencional de la verdad de lo que se dice es crucial para definir aquella mentira ${ }^{21}$, comunicar algo distinto que la verdad de lo que se dice no siempre constituye una desviación ilegítima en la política, y más bien es casi que la norma. Sin embargo, lo anterior no implica que todo uso del lenguaje en política sea mendaz. No podría haber una definición de la mentira política más inútil (y más pesimista) que aquella que afirmara seriamente el viejo chiste de que para saber cuándo mienten los políticos, hay que fijarse solamente en si están moviendo los labios.

Para precisar la característica de la mentira política que quiero identificar en esta sección, considérese la distinción entre convencer y persuadir introducida por Perelman y Oldbrechts-Tyteca (1969)22. Para estos autores, una argumentación persuasiva es aquella que reclama validez solamente para una audiencia particular, mientras que una argumentación que busca convencer es una que pretende ganar la adhesión de todo ser racional (Perelman \& Oldbrechts-Tyteca, 1969, p. 28). Dicho de otra forma, persuadir y convencer difieren en función de la extensión de las respectivas audiencias. Pero una audiencia puede ser particular

21 En el debate contemporáneo sobre la mentira, Bok (2010, p. 60) es la autora que admite más claramente la presunción en favor de la regla de la veracidad. Baier (1993), por el contrario, la rechaza en su interpretación de la virtud de la veracidad en los textos de Hume. La regla de la veracidad, con todo, no parece derivarse directamente de la naturaleza del lenguaje. Arendt comenta: "las mentiras solo pasaron a ser consideradas como infracciones graves con el surgimiento de la moral puritana, que coincidió con el auge de la ciencia organizada, cuyo progreso debía asegurarse en el terreno firme de la veracidad y la credibilidad absoluta de cada científico" (Arendt, 1967/2017a, p. 25). Para interesantes reconstrucciones de los cambios culturales y morales que llevaron a la prevalencia de la regla de la veracidad en casi todos los ámbitos de la vida individual y social contemporánea, ver Trilling (1971-1972), Shapin (1995), Williams (2002) y Foucault (2010). En un tono similar, Jay (2010) describe, en la introducción a su texto, algunos de los factores que llevaron a convertir en fetiches morales a valores como la veracidad, la transparencia y la sinceridad en el discurso público norteamericano.

22 Estos autores advierten que su distinción es diferente de la famosa distinción kantiana entre los mismos términos. 
no solo por su número o por las características comunes, aunque específicas de sus miembros (los colegas parlamentarios, los representantes de una agencia gubernamental, los ciudadanos de una determinada nación, los miembros de cierto partido), sino también por su duración temporal: en un discurso en la plaza pública, la audiencia está conformada por quienes estén en la plaza, y durante el tiempo en que lo estén. En una campaña electoral, el público a persuadir existe hasta las votaciones.

Esta forma de distinguir persuasión de convencimiento impide equiparar persuasión y mentira. La persuasión no es una forma inferior o fraudulenta del convencimiento, a la que el hablante recurre cuando advierte que carece de argumentos de validez universal. Más bien, la persuasión es una manera alternativa, y legítima en ciertos contextos, de ganar la adhesión epistémica y pragmática de otros $^{23}$. La persuasión es apropiada allí donde el mensaje que se quiere transmitir busca, más que simplemente comunicar información, motivar una decisión de acción concreta. Esto implica que los criterios con los que se puede evaluar legítimamente a un intento de persuasión dado no se limitan a la verdad o falsedad del contenido, o al éxito o fracaso en la motivación a la acción, sino que incluyen la moralidad o inmoralidad de las razones para motivar a la acción concreta. Ahora bien, el lenguaje en política es predominantemente persuasivo, o mejor dicho, con él se busca la mayoría de las veces ganar la adhesión de aquellos cuyas actitudes, acciones o disposiciones se necesita movilizar en un lugar y momento histórico dados: el electorado, los gobernados, los políticos rivales, los co-partidarios o, incluso, los enemigos. Por ello, la veracidad de lo dicho, y lo literalmente dicho, son elementos contingentes de los mensajes políticos: para persuadir a su particular audiencia, el político puede recurrir, en principio, tanto a la afirmación directa y veraz o al recurso retórico veraz, como a sus análogos mendaces. En otras palabras, en política, el lenguaje no se usa para ganar la adhesión de todo ser racional, sino solamente de aquellos que importan ${ }^{24}$.

23 Hay un interesante paralelo entre esta forma en que se contraponen convencer y persuadir, de un lado, y la discusión sobre las diferencias entre conocimiento y opinión política que propone Arendt (1967/2017a), del otro.

24 En contraste, ganar la adhesión universal es el objetivo de la ciencia política o de la filosofía política. No obstante, lo anterior no excluye la posibilidad de que, en el intento por ganar la adhesión de una 
Williams (2005) sugiere una idea similar al preguntarse si la política puede entenderse como un método de búsqueda y transmisión de la verdad. Los procesos y sistemas políticos no están, por su naturaleza, pensados para asegurar el descubrimiento o la comunicación de la verdad. Más bien, idealmente, los sistemas políticos están diseñados para la toma justa y eficiente de decisiones. Es por ello que nadie se sorprende de que los actores políticos no sean modelos de transparencia, o de que las reglas de su práctica se alejen considerablemente de las reglas de la práctica científica o filosófica ${ }^{25}$. Desde luego, como también apunta Williams (2005, p. 162), hay ciertos tipos de investigación y comunicación de la verdad que son imprescindibles para cualquier clase de intercambio lingüístico, y más aún, para los intercambios que tienen lugar cuando se administran recursos. Como mínimo, es deseable que cualquier método de investigación evite el razonamiento ilusorio ("wishful thinking") (Williams, 2005, p. 156) y que aspire, en cuanto sea posible, a generar resultados "tales que $\mathrm{P}$ (si P) y que no $\mathrm{P}$ (si no P)” (Williams, 2005, p. 156; traducción propia) ${ }^{26}$. Y, en efecto, la administración burocrática de recursos es algo que ciertos políticos hacen, o a lo que al menos contribuyen normalmente, cuando se definen los detalles de las políticas públicas o cuando tienen que entregar información relevante para su ejecución y control. Pero si se piensa en su uso más visible en política, el lenguaje sirve allí a fines que tienen que ver más con el manejo del desacuerdo, la superación de los conflictos de valores y el logro de acuerdos entre intereses rivales, que con las virtudes de la veracidad ${ }^{27}$.

audiencia particular, los actores políticos invoquen a veces valores, creencias u opiniones que, en sí mismos, ameritan adhesión universal.

25 En un pasaje frecuentemente citado, Arendt (1967/2017a) anota: "nadie ha dudado jamás con respecto al hecho de que la verdad y la política no se llevan demasiado bien, y nadie, que yo sepa, ha colocado a la veracidad entre las virtudes políticas" (p. 15).

"such that $P$ (if $P$ ), and not $P$ (if not $P$ )".

27 Grant (1997) sostiene que esta es la lección política fundamental en la obra de Maquiavelo. Según esta autora, para Maquiavelo, "la política se trata de crear asociaciones útiles con personas, cuyos intereses coinciden solo parcialmente con los propios [...] [se trata de crear asociaciones] con gente que en últimas compite con uno" (p. 21; traducción propia). ["politics is about creating useful partnerships with people whose aims overlap, but do not coincide with, your own [...], with people who are ultimately your competitors"]. Waldron (1999) denomina "circunstancias de la política" 
Nótese que esta observación sobre el uso del lenguaje en la política no significa un compromiso con una definición particular de lo político. Casi cualquier definición de lo político admitiría la idea de que el uso del lenguaje en la política no es igual a su uso en la investigación científica y que tiene que ver con la acción, más que con las creencias. La conclusión que quiero señalar por el momento es que una definición de la mentira política debería atender al uso especial que predominantemente se le da al lenguaje en política. El lenguaje en política se usa para persuadir, aunque esto no significa que la persuasión sea intrínsecamente mendaz. La pregunta que surge, entonces, es por la naturaleza específica de la mentira política. Si no es en la desviación deliberada en el uso literal y veraz del lenguaje, entonces, ¿̇en qué consiste?

\section{Mentira y discusión política}

Para aVAnZar mi propuesta sobre lo característico de la mentira política, considérense los fenómenos del "negacionismo científico" y de las "noticias falsas". El negacionismo científico es la estrategia de desprestigio deliberado y sistemático de un concepto, teoría, campo o fuente científica, en favor de los intereses económicos o políticos de quien la promueve (McIntyre, 2018, p. 17). Uno de los casos más escandalosos de esta práctica fue protagonizado por la industria del tabaco en Estados Unidos. Proctor (2011) describe las tácticas que desplegaron los empresarios del tabaco para contrarrestar los peligros que las investigaciones médicas sobre los efectos del consumo de cigarrillos representaban para su negocio. Desde al menos la segunda década del siglo XX, múltiples investigaciones médicas empezaron a indicar una posible conexión entre el consumo regular de cigarrillos y varios tipos de cáncer, especialmente el cáncer de pulmón. Frente a tales resultados, la táctica de las compañías había sido defensiva, enfatizando en su publicidad que sus cigarrillos eran menos perjudiciales que los de la compañía rival. Sin embargo, hacia la mitad del siglo, la evidencia parecía contundente y la comunidad científica parecía haber llegado a un consenso sobre la relación

precisamente a la clase de situaciones en las que se requiere llegar a acuerdos que lleven a la acción en concierto con otros que no comparten los propios valores, opiniones o creencias (p. 102). 
causal: fumar mata ${ }^{28}$. Por ello, en 1953, los líderes de la industria fundaron el Comité de Investigación de la Industria Tabacalera ${ }^{29}$, cuya función principal era crear duda en el público sobre la validez de las investigaciones científicas sobre los efectos del tabaco (McIntyre, 2018, p. 21; Proctor, 2011, p. 289). La pieza central de esa estrategia fue contratar científicos dispuestos a fabricar evidencia contraria a la que provenía de las agencias de salud de los gobiernos y de los laboratorios independientes y darla a conocer al público con inusitada intensidad. Para la industria del tabaco, no era necesario que la evidencia se generara de acuerdo con estándares científicos. De hecho, muchos de los resultados eran simples mentiras expresadas en jerga científica.

Esta producción de duda, respaldada tan agresivamente por una de las industrias con mayor capital en el mundo, resultó efectiva. Desde los años sesenta, los consumidores dejaron de prestar atención a las investigaciones provenientes de las agencias de salud de sus gobiernos y las tildaron de precarias, inconclusas, partidarias, procomunistas e, incluso, contrarias a su libertad de conciencia y de expresión y a la libertad de empresa de la industria (Proctor, 2011, p. 333). La gravedad del daño no consistió solamente en que los fumadores siguieron fumando y muriendo, mientras que las utilidades de la industria crecían, sino que la propaganda protabaco logró implantar en el ciudadano corriente una imagen distorsionada de la actividad científica, de sus estándares epistémicos y de la manera apropiada de discutir y criticar la evidencia factual. La estrategia anticientífica de los tabacaleros pronto fue copiada por la industria del petróleo y dirigida, desde finales de los años noventa, contra la tesis del calentamiento global (McIntyre, 2018, p. 27). Más tarde, se convirtió en la maniobra usual de cualquiera que viera que sus intereses o valores eran amenazados por la evidencia científica, o que simplemente intentara sacar provecho de la confusión

28 Para aclarar, se había llegado al consenso de que la evidencia indicaba, con un alto grado de confianza, que el consumo frecuente de cigarrillos era la causa de varias enfermedades crónicas. Naturalmente, ninguna investigación empírica puede establecer con certeza absoluta la relación causal entre dos hechos. 
del público sobre algún asunto que involucrara una interpretación de hechos (Rabin-Havt, 2016) ${ }^{30}$.

Por su parte, las noticias falsas son "afirmaciones falsas que pretenden referirse al mundo [real] mediante un formato y con un contenido que se asemeja al formato y al contenido de organizaciones de noticias legítimas" (Levy, 2017, p. 20; traducción propia $)^{31}$. Un caso reciente fue el "Pizzagate", en el que un vigilante, motivado por información falsa que circulaba en redes sociales, irrumpió fuertemente armado a la pizzería Comet Ping Pong en Washington D. C., con la intención de acabar con el supuesto negocio de tráfico de personas que Hillary Clinton mantenía allí (Rini, 2017, p. E48). La diseminación de noticias falsas no siempre es deliberada y no siempre persigue intereses reconociblemente políticos ${ }^{32}$, pero produce un efecto similar al del negacionismo científico: promueve una imagen distorsionada de la realidad y, más aún, de la actividad y estándares de quienes buscan reportarla imparcialmente. Como señala McGonagle (2017, p. 206), hay ciertas características que hacen a este fenómeno más preocupante

30 El negacionismo científico involucra varias formas de engaño, no solamente la mentira. Sin embargo, representa un claro ejemplo de lo que Arendt (1967/2017a, p. 61) llama la "mentira moderna": aquella mentira organizada y sistemática, promovida por intereses económicos y políticos poderosos, dirigida a todos los ciudadanos sin distinciones y encaminada no tanto a remplazar unas de sus creencias por otras, sino a destruir su sentido de la realidad.

31 "Fake news is the presentation of false claims that purport to be about the world in a format and with a content that resembles the format and content of legitimate media organisations." Talisse (2018) sostiene que es imposible definir qué cuenta como una noticia falsa sin incurrir en partidismo. McGonagle (2017) las define como "desinformación que es presentada, o es probable que sea percibida como, noticias" (p. 203, traducción propia) ["disinformation that is presented as, or is likely to be perceived as, news"]. Las noticias falsas no son un fenómeno reciente. Según McIntyre (2018, p. 97), para algunos, las noticias falsas son tan antiguas como las noticias mismas. La idea no es irrazonable, si se toma en cuenta que el concepto de objetividad periodística y su valoración como guía de la labor organizada y profesional de reportar los hechos son nociones relativamente recientes (quizás de finales del siglo XIX); mucho más reciente, en todo caso, que la diseminación de noticias impresas. Pero, además, la información parcial, incluso partidista, se veía a comienzos del siglo XX en Norteamérica como una respuesta válida frente al monopolio de información que detentaban los poderes políticos y económicos (McIntyre, 2018, pp. 103-104). McIntyre (2018, p. 104) sugiere que las noticias falsas nos sorprenden más que todo porque nos hemos acostumbrado, al cabo de un siglo, a esperar neutralidad en nuestras fuentes de información.

32 También hay noticias falsas sobre las celebridades de Hollywood o sobre los efectos de ciertos productos comerciales de consumo masivo. 
hoy en día: dada la sofisticación con que son producidas, las noticias falsas son más difíciles de reconocer; y dado el número en el que son producidas y la velocidad de su difusión, son más difíciles de evitar y, en consecuencia, sus fuentes y efectos son más difíciles de rastrear y contrarrestar. El resultado, de nuevo, es la incertidumbre, el desprestigio de las fuentes tradicionales de información y la distorsión de los estándares para juzgar sus afirmaciones.

Es aquí, a mi juicio, donde podemos encontrar el rasgo central de las mentiras políticas. Mi tesis es que la mentira política se caracteriza porque su función no es, o no es solamente, implantar creencias falsas en sus destinatarios, sino más bien socavar diversas clases de condiciones epistémicas que son necesarias para la discusión imparcial de los desacuerdos sociales. El concepto de mentira política así propuesto no es coextensivo con el de negacionismo científico, ni con el de noticias falsas, pero tiene en común con estos la idea de que el efecto de las mentiras políticas es afectar las decisiones y acciones de aquellos a quienes se dirigen, mediante la manipulación de las condiciones epistémicas que permiten la adecuada discusión pública. Esta tesis encaja con la idea de que el lenguaje de la política apunta a la persuasión de aquellos que tienen intereses y valores diferentes a los propios. La mentira política es, entonces, una forma tramposa de ganar la adhesión epistémica y así motivar a la acción a quienes no comparten exactamente los propios valores, creencias u opiniones.

Para lograr este objetivo, una mentira política no tiene que ser creída literalmente por aquellos a quienes se dirige. Basta con que cree estados epistémicos tales que lleven a la acción que el mentiroso desea ${ }^{33}$. Así como los tabacaleros, para mantener sus ventas, no necesitaban que sus compradores creyeran que el consumo regular de cigarrillos no causaba cáncer, sino solamente que dudaran de la evidencia científica al efecto, así el éxito de algunas mentiras políticas consiste solamente en generar duda (¿cuál es realmente la diferencia entre firmar

33 Fallis y Mathiesen (2017) sostienen que para entender la manera en que funcionan las mentiras políticas es crucial rechazar la idea de que mentir a un grupo de individuos es igual a mentir a cada uno de los individuos que conforman el grupo por separado ("summative plank"). Cuando los políticos mienten a grupos de individuos, pueden aprovecharse de las ventajas de la comunicación masiva, del "targeting" de subgrupos o apelar a presuposiciones compartidas, como la identidad colectiva o las creencias comunes o de grupo. Cuando el político apela a tales "ventajas" epistémicas, como anotaré a continuación en el texto, podría entenderse que comete una especie de trampa. 
un acuerdo de paz con la guerrilla y adherir a sus ideales?), despertar emociones ("queríamos que la gente saliera a votar verraca"), y el de otras en activar prejuicios o ciertas disposiciones ("ustedes, los intelectuales que aún viven en la comunidad basada en los hechos", "no creo en las estadísticas, sino en lo que me dicta el instinto").

En este sentido, la estructura de la especie "mentira política" guarda sugerentes parecidos con la trampa y el gaslighting ${ }^{34}$. Según Green (2006), hay dos elementos que definen el hacer trampa: romper cierto tipo de reglas y romperlas con el objetivo de obtener una ventaja injusta. Cuando se hace trampa, según Green, se rompen las reglas obligatorias, que definen o regulan una práctica, en parte cooperativa en parte competitiva, en la que sus participantes se comprometen a limitar su libertad en favor del beneficio que la práctica promete (Green, 2006, p. 58). El tramposo rompe tal clase de reglas porque de esa forma asegura una ventaja frente a sus competidores, una ventaja que no está permitida por las reglas de la práctica (Green, 2006, p. 63). El mentiroso político es una especie de tramposo. Con el objetivo de lograr una ventaja en la discusión política, el mentiroso rompe las reglas que garantizan un cierto nivel de calidad del debate (reglas que pueden estar consagradas explícitamente en normas jurídicas o en normas políticas consuetudinarias). En lugar de las tácticas argumentativas y retóricas veraces para lograr la cooperación y la acción en concierto con los otros, el mentiroso político busca generar estados epistémicos mediante los que obstaculiza el apropiado examen, de aquello que defiende, por parte de los demás. En efecto, algunas mentiras políticas tienen como función perturbar la formación de la voluntad y la toma de decisiones colectivas, procesos usualmente regidos por normas más o menos definidas en la ley o establecidas por la práctica política del país.

34 El gaslighting es un tipo extremo de manipulación psicológica. No existe, a mi juicio, un término en español que se refiera al mismo fenómeno. El nombre de gaslighting se deriva de la obra de teatro Gaslight, escrita por Patrick Hamilton y presentada por primera vez en 1938 y luego llevada al cine por el director Thorold Dickinson en 1940. En la historia, un esposo manipula psicológicamente a su esposa con el fin de quedarse con las joyas de esta. En varias escenas, el esposo sube al ático de la casa en la que ambos viven a buscar las joyas. Dado que las luces del ático dependen del mismo defectuoso sistema de gas de las del resto de la casa, cada vez que él prende aquellas, las demás luces pierden intensidad. 
Otras mentiras políticas se dirigen a afectar otro conjunto de condiciones epistémicas que, a falta de mejor término, podrían clasificarse como subjetivas. En este aspecto, algunas mentiras políticas se parecen al gaslighting. De acuerdo con Abramson (2014), el gaslighting es "una forma de manipulación emocional en la que el gaslighter intenta [...] inducir en el otro la impresión de que las reacciones, percepciones, memorias y/o creencias de esta otra persona no solo son erradas, sino carentes de todo fundamento" (p. 2; traducción propia) ${ }^{35}$, al punto de que la víctima misma llega a considerarlas como propias de un demente. Esta forma de manipulación requiere de múltiples incidentes a lo largo del tiempo, mediante los cuales el gaslighter gradualmente aísla a su víctima de la realidad, hasta que esta deja de confiar en sus propias capacidades para distinguir cuáles de sus creencias son confiables y cuáles no. Mediante su estrategia, el gaslighter, en últimas, busca destruir la posibilidad de toda forma de desacuerdo con su propia visión del mundo, aniquilando las competencias de la otra persona para la deliberación y la discusión racional. De allí que las tácticas de las que el gaslighter se vale no solo se dirijan a refutar o a descartar posiciones u opiniones particulares que la víctima pueda adoptar, sino a eliminarla a ella misma como fuente de posible desacuerdo (Abramson, 2014, p. 10). Algunas mentiras políticas se asemejan al gaslighting: sistemática y gradualmente eliminan la posibilidad de desacuerdo, aniquilando las capacidades epistémicas de aquellos a quienes se dirigen. Si son exitosas, las mentiras políticas así desplegadas terminan despojando del juicio a aquellos a quienes se dirigen y logran así que el líder político, el partido, o el Estado sean quienes determinen cuáles creencias hay que adoptar y, por ende, cuáles acciones que hay que ejecutar.

Mi propuesta de caracterización de la mentira política podría entenderse como un replanteamiento de la definición tradicional de la mentira, en especial de su primera, tercera y cuarta condiciones ${ }^{36}$. Sostengo que hay mentira política

35 "a form of emotional manipulation in which the gaslighter tries [...] to induce in someone the sense that her reactions, perceptions, memories and/or beliefs are not just mistaken, but utterly without grounds".

36 Recuérdese en este punto la reflexión de la nota 1 sobre la pregunta de si hay alguna distinción significativa entre la tesis de que la mentira política es diferente a la mentira común y la tesis de que la mentira política es un tipo o caso especial de la mentira común. 
cuando i) se dirige un enunciado (posiblemente retórico), ii) que se cree falso, o no se cree verdadero, iii) a una audiencia con capacidad de decidir y actuar sobre asuntos sociales, iv) con el fin de socavar diversas clases de condiciones epistémicas que son necesarias para la discusión imparcial de las decisiones y acciones sobre aquellos asuntos.

Esta caracterización supone que en la actividad política rigen reglas de comunicación diferentes a las del lenguaje cotidiano o del lenguaje propio de la investigación científica o filosófica. Esto se compadece con el hecho de que la política no es una actividad en la cual sea razonable esperar relaciones basadas en la completa sinceridad o transparencia. Esta es la razón central por la cual mentir en política no es igual a mentir en otros ámbitos y, por lo tanto, la razón a partir de la cual se sigue que las respectivas definiciones de mentir deban ser distintas.

En esta propuesta, expreso la primera condición mediante una construcción impersonal ("se dirije") para evitar incluir como parte de la caracterización de la mentira el requisito de que alguien dirija deliberadamente el enunciado de la siguiente condición. Esto se debe a que hay algunos enunciados que son producidos con fines distintos de los de las mentiras políticas, pero que una vez entran en el dominio público son promovidos de manera que cumplan la función propia de las mentiras políticas. Un caso claro es el de las fake news creadas con fines publicitarios (clickbait), pero que luego son redirigidas a objetivos políticos. En esta misma condición, incluyo la posibilidad de que el enunciado sea expresado retóricamente con el fin de incluir los casos de mentiras por desorientación, falsa presuposición, ironía o lenguaje codificado, así como los casos de ambigüedad en los que el hablante deja abierto a interpretación si quiere decir algo sobre los hechos o sobre sus creencias sobre los hechos. La segunda condición busca mantener un rasgo central de la mentira en general: se dice (en sentido amplio) algo falso, o que no se cree verdadero. La tercera condición constituye la mitad de la explicación de lo que hace específica a la mentira política: es una mentira que aparece en una clase particular de discusiones, definida por la audiencia. La capacidad de decidir y actuar sobre asuntos sociales puede estar formal o informalmente establecida; lo esencial en este punto es que el resultado es una decisión legítima y con el potencial de alterar las condiciones sociales de la vida en común. Finalmente, la cuarta condición remplaza el requerimiento de que para mentir en política debe existir la intención de engañar. En mi propuesta, lo 
crucial en la mentira política es que el enunciado falso permite ventajas injustas para alguna de las partes de la discusión o que socava la competencia epistémica de los participantes en la discusión política. La mentira es política precisamente porque consiste en una forma anormal y quizás ilegítima de persuadir a los demás en discusiones sobre asuntos sociales. En conjunto, las condiciones de esta caracterización implican que lo distintivo de la mentira política no es el simple falseamiento deliberado de la verdad, sino la perturbación de las condiciones epistémicas que permiten la toma imparcial de decisiones ${ }^{37}$.

\section{Algunas aclaraciones y consecuencias}

\section{i. LO CARACTERÍSTICO DE LA MENTIRA POLÍTICA no es el falseamiento deliberado} de la verdad. Afirmar que lo especial de la mentira política no es el falseamiento deliberado de la verdad no implica afirmar que los políticos no mienten cuando sus mentiras no se ajustan a mi definición, sino solamente que no están diciendo mentiras políticas. En efecto, los políticos pueden ocupar también otros roles, en virtud de los cuales pueden estar obligados a decir la verdad, o a ser sinceros. Para describir tales mentiras, las definiciones de la mentira común pueden ser suficientes.

Por otro lado, negar que el falseamiento de la verdad no es suficiente para definir la mentira política no implica negar que hay situaciones en las que decir la verdad constituye una acción política, pues, como sostiene Arendt (1967/2017a), "allí donde una comunidad se embarca en la mentira organizada por principio, y no únicamente con respecto a asuntos particulares, puede la veracidad $[\ldots]$ convertirse en un factor de primer orden" (p. 58). De hecho, la

37 ¿Por qué llamar a tales condiciones "condiciones epistémicas"? La respuesta corta es que me refiero a condiciones que establecen cómo se debe recoger y evaluar la evidencia y cómo se deben valorar los argumentos que son discutidos entre las partes de la tercera condición. Otra pregunta que podría surgir en este punto es si el cambio que propongo en la cuarta condición implica que la mentira política deja de ser una forma de engaño. No creo que este sea el caso. Aquello que caracteriza esencialmente la acción de engañar es lograr que el destinatario del engaño crea algo, falso o que el que engaña no cree verdadero, y que es diferente a lo que el destinatario de hecho cree. Mi propuesta conserva esta idea, pero la extiende a la discusión persuasiva: la función de la mentira política es alterar ilegítimamente las condiciones en las que ciertas audiencias se persuaden mutuamente para formar las opiniones y tomar las decisiones que las afectan. 
expresión pública y repetida de la verdad puede ser la mejor forma de combatir a los mentirosos políticos ${ }^{38}$.

ii. La mentira politica tiene que ver con cierta violación de la confianza. Hay un sentido en que la confianza no tiene lugar en la política: la política no es una actividad exclusivamente cooperativa. Como sugiere la idea de las "circunstancias de la política" de Waldron (1999, p. 102), la política tiene que ver con el desacuerdo y el conflicto: sin estos elementos, no habría ni siquiera necesidad de política. Pero hay otro sentido en que mi propuesta sobre la mentira política la vincula con cierta violación de la confianza legítima. A la luz de las comparaciones con la trampa (cheating) y el gaslighting, las mentiras políticas constituyen atajos ilegítimos, trampas de las que se vale el actor político para lograr un acuerdo o motivar un curso de acción en otros, mediante la destrucción de las posibilidades mismas de que estos otros se opongan legítimamente. La mentira política, en tal sentido, constituye una violación a la confianza legítima que pueden tener los participantes de la práctica antagónica (Applbaum, 1999) del debate de persuasión.

iii. Mi propuesta permite apreciar varias complejidades de la mentira politica y sus conexiones con otros fenómenos. La primera complejidad que permite apreciar es que la mentira política no es provocada ni exclusiva, y muchas veces tampoco principalmente, por individuos que hacen parte del aparato estatal. De hecho, la mentira política no puede definirse en función de su autor. La mentira política puede ser cometida por individuos o grupos de cualquier clase con interés de ganar un asunto que es objeto de persuasión en la discusión pública o simplemente de obstaculizarlo: líderes políticos, agencias estatales, medios de comunicación, grupos de interés, asociaciones de ciudadanos o individuos aislados, grupos de oposición o de resistencia política, líderes o miembros de otros estados, o incluso miembros de organizaciones internacionales, legales o ilegales. Por supuesto, los grupos políticos en el poder tienen más incentivos para generar y propagar ciertas mentiras políticas. Pero, en ocasiones, la acción del mentiroso se limita

38 Estudios recientes sugieren que, a pesar de todas las formas de sesgo cognitivo que las mentiras políticas pueden explotar (en especial el llamado "backfiring effect"), existe también un punto límite: un grado alto de exposición permanente y fundada a la verdad puede lograr que quienes están radicalmente persuadidos de una mentira logren salir de tal estado. Véase Redlawsk, Civettini y Emmerson, 2010. 
a provocar las condiciones que facilitan que otros agentes produzcan mentiras políticas inadvertidamente. Las noticias falsas y las teorías de la conspiración que fluyen a través de redes sociales son ejemplos pertinentes.

Dada esta complejidad, no es sorprendente que, para trazar el origen y adjudicar las responsabilidades de mentiras políticas dadas, surjan problemas como el de las "manos múltiples" (Thompson, 1999), o el de decidir si es más conveniente fijarse en el contexto o las causas subyacentes que hacen posibles a las mentiras políticas o en las motivaciones individuales de los políticos mentirosos. Finalmente, el sentido e impacto de las mentiras políticas no puede considerarse siempre aisladamente. Como sugiere la comparación con el gaslighting, las mentiras políticas usualmente hacen parte de un sistema. En efecto, el éxito real de las mentiras políticas suele verse solo a largo plazo, cuando los esfuerzos graduales y organizados de los propagadores han surtido efecto. No es una mera excentricidad que el conteo de mentiras de Trump no pare de $\operatorname{crecer}^{39}$. Además, entender las mentiras políticas como parte de un sistema permite conectarlas más fácilmente con otras formas de engaño, frecuentes en la era de la posverdad, y a las que, en conjunto, se recurre para pervertir el juicio de los ciudadanos: la charlatanería (bullshit), y la interpretación sesgada (spin), las medias verdades, el secreto ilegítimo, la desinformación, etc.

iv. Mi propuesta deja abierta la discusión sobre el mal moral que esa clase de mentira puede producir. Una de las dificultades al definir la mentira común y corriente es decidir si se trata de un concepto intrínsecamente moral. Kemp y Sullivan (1993) y Margolis (1962) sostienen que la afirmación "mentir es moralmente reprochable" es tautológica. Estos autores alegan que definir "mentira” sin atender a la carga moral que se quiere transmitir es ignorar la naturaleza misma del término. Sin embargo, otros autores en este mismo debate, como mencioné atrás, consideran importante distinguir entre las cuestiones conceptuales y las cuestiones normativas (Carson, 2010; Chisholm \& Feehan, 1977; Mahon, 2016). No obstante, si mi propuesta es correcta, no es posible establecer con detalle qué es la mentira política sin esclarecer cuestiones que, aunque no son

39 Según el Toronto Star, Trump habría dicho 1.972 mentiras entre la fecha de su posesión como presidente y el 12 de julio de 2018. Según el Washington Post, el conteo de mentiras había ascendido a 8.718 para el 17 de febrero de 2019 . 
morales, sí son normativas y tienen que ver con cuáles sean las reglas y condiciones ideales, epistémicas y morales, para la discusión de los desacuerdos sociales. La mentira política es un concepto completamente normativo, en tanto describe una clase de acción, al tiempo que la ubica en un espectro valorativo, como mínimo, de carácter epistémico.

Quizás la motivación detrás de la distinción entre cuestiones conceptuales y normativas tiene que ver con la necesidad de aislar las preguntas relacionadas con el mal moral que las mentiras pueden producir. Pero entendida de esta manera, la distinción simplifica el problema. Sería más apropiado considerar el mal moral de las mentiras mediante la distinción entre daño (harm) y perjuicio (wrong $)^{40}$. El daño tiene que ver con los obstáculos o desventajas que se producen en el bienestar de una persona o grupo, mientras que el perjuicio tiene que ver con la violación de una regla moral o un derecho legítimo en cabeza de alguien. Tanto las mentiras como las mentiras políticas pueden producir daños y perjuicios, o solamente unos o los otros. $Y$ aunque, en este esquema, solo sean moralmente reprochables los perjuicios, esto no significa que los daños no exijan alguna medida de corrección o reparación. Esta última consideración es relevante para una reflexión acerca de cuál sea la sanción legal más apropiada para las mentiras políticas.

\section{Conclusión: políticos mentirosos y tramposos democráticos}

¿CuÁles son exactamente las condiciones epistémicas necesarias para la discusión de los desacuerdos sociales o para la discusión política? ¿Cuáles son exactamente las reglas que supuestamente rompen los mentirosos políticos? La defensa de un modelo de discusión y persuasión política supera el objetivo y la extensión de este artículo. No obstante, creo que es posible señalar al menos dos alternativas que podrían complementar mi propuesta en esa dirección. En primer lugar, está la sugerencia de Arendt, especialmente en "Verdad y política” (1967/2017a, pp. 42-43), según la cual la "opinión imparcial” constituye la forma legítima del conocer político, una forma que se nutre tanto de la verdad

40 Para una instructiva discusión sobre estos dos conceptos, véase Feinberg, 1984, pp. 31-36. 
factual (establecida trabajosamente por parte de historiadores, periodistas y jueces), como del esfuerzo individual y colectivo por representar imparcialmente los puntos de vista de los demás. Arendt no desarrolla cabalmente esta propuesta, pero se podría especular que, en esta concepción, la mentira política sería aquella forma de usar el lenguaje que obstaculiza la formación imparcial de la opinión política.

La otra alternativa es el llamado "giro epistémico" en la concepción de la democracia deliberativa, iniciado, entre otros autores, por Elizabeth Anderson $(2006)^{41}$. La idea central de este "giro" se resume en el eslogan "la democracia no consiste solo en votar, sino también en hablar". Para Anderson, el potencial de la democracia, como mecanismo de toma de decisiones, solo puede aprovecharse completamente si se explota la contribución de agentes epistémicamente diversos comprometidos con las tareas de deliberar, tomar decisiones, aprender de los fracasos y corregir los errores de decisiones pasadas. La mentira política, en esta concepción, sería una forma de obstaculizar el proceso de aprendizaje y auto-mejoramiento colectivo que permiten las democracias. La socavación que se produce mediante la mentira política podría articularse alternativamente en el modelo de los deberes y responsabilidades o en el de las virtudes y los vicios epistémicos.

Mediante la propuesta que defendí en este trabajo busqué articular la intuición de que la mentira política es peculiar porque, además de transmitir creencias falsas o fracturar la confianza social, se caracteriza por estropear las condiciones de posibilidad o la calidad de las discusiones sobre los problemas que nos afectan a todos. Esto no implica que la mentira política, así concebida, sea inexistente en regímenes no democráticos, pues no hay orden político que no descanse en mayor o menor grado en la opinión de los gobernados. Pero sí implica que no debemos sorprendernos de que las democracias constituyan un suelo fértil para las mentiras políticas. Porque la democracia es el régimen en el que la discusión política depende más que en cualquier otro de frágiles esquemas de formación colectiva de creencias y opiniones; es el régimen en el que las mentiras políticas son más frecuentes. También en el que pueden ser más grandes y más graves.

41 Para una revisión de la literatura pertinente y una propuesta novedosa y sugerente de las ventajas epistémicas de la deliberación democrática, véase Landemore, 2013. 
Referencias

Abramson, K. (2014). Turning Up the Lights on Gaslighting. Philosophical Perspectives, Ethics, 28(1), 1-30. doi: 10.1111/phpe.12046

Anderson, E. (2006). The Epistemology of Democracy. Episteme, 3(1), 8-22. doi:10.1353/epi.0.0000

Applbaum, A. I. (1999). Ethics for Adversaries. The Morality of Roles in Public and Professional Life. Princeton: Princeton University Press.

Arendt, H. (1997). ¿Qué es la política? Barcelona: Paidós.

Arendt, H. (2006). Los origenes del totalitarismo. Madrid: Alianza.

Arendt, H. (2017a). Verdad y política. En: Verdad y mentira en la política (pp. 11-80). Barcelona: Página Indómita.

Arendt, H. (2017b). La mentira en la política. En: Verdad y mentira en la política (pp. 81-142). Barcelona: Página Indómita.

Baier A., (1993). Why Honesty is a Hard Virtue? En: O. Flanagan \& A. Oksenberg Rorty (Eds.). Identity, Character, and Morality: Essays in Moral Psychology (pp. 259-282). Cambridge: MIT Press.

Barnes, J. A. (1994). A Pack of Lies: Towards A Sociology of Lying. Cambridge: Cambridge University Press.

Bok, S. (2010). Mentir. La elección moral en la vida pública y privada. Ciudad de México: Fondo de Cultura Económica.

Carson, T. (2010). Lying and Deception. Theory and Practice. Oxford: Oxford University Press.

Chisholm, R., \& Feehan, T. (1977). The Intent to Deceive. The Journal of Philosophy, 74(3), 143-159.

Coleman, L., \& Kay, P. (1981). Prototype Semantics: The English Verb 'lie'. Language, 57(1), 26-44.

Ekman, P. (2005). Cómo detectar las mentiras. Una guia para utilizar en el trabajo, la politica y la familia. Barcelona: Paidós.

El tal paro nacional agrario no existe. (2013, agosto 25). Dinero. Recuperado de: https://www.dinero.com

Fallis, D. (2009). What is Lying? Journal of Philosophy, 106(1), 29-56. doi: 10.5840/jphil200910612 
Fallis, D., \& Mathiesen K. (2017). "The Greatest Liar Has His Believers": The Social Epistemology of Political Lying. En: E. Crookston, D. Killoren, \& J. Trerise (Eds.). Ethics in Politics (pp. 35-53). London: Routledge.

Feinberg, J. (1984). Harm to Others, New York: Oxford University Press.

Foucault, M. (2010). El coraje de la verdad. El gobierno de siy de los otros II. Curso en el College de France (1983-1984). F. Gros (Ed.). Buenos Aires: Fondo de Cultura Económica.

Gardiner, J. (2007). Defining Corruption. En: A. Heidenheimer, \& M. Johnston (Eds.). Political Corruption. Concepts and Contexts (pp. 25-40). New Brunswick: Transaction Publishers.

Grant, R. W. (1997). Hypocrisy and Integrity. Machiavelli, Rousseau and the Ethics of Politics. Chicago: The University of Chicago Press.

Green, S. P. (2006). Lying, Cheating, and Stealing. A Moral Theory of WhiteCollar Crime. Oxford: Oxford University Press.

Hardin, K. J. (2010). The Spanish Notion of Lie: Revisiting Coleman and Kay. Journal of Pragmatics, 42(12), 3199-3213. doi: 10.1016/j.pragma.2010.07.006

Jay, M. (2010). The Virtues of Mendacity: On Lying in Politics. CharlottesvilleLondon: University of Virginia Press.

Kemp, K. W., \& Sullivan T. (1993). Speaking Falsely and Telling Lies. Proceedings of the American Catholic Philosophical Association, 67(1), 151-170.

Koyré, A. (1945). The Political Function of the Modern Lie. Contemporary Jewish Record, 8(3), 290-300.

Landemore, H. (2013). Democratic Reason. Politics, Collective Intelligence, and the Rule of the Many. Princeton: Princeton University Press.

Levy, N., (2017). The Bad News About Fake News. Social Epistemology Review and Reply Collective 6(8), 20-36.

Mahon, J. (2016). The Definition of Lying and Deception. En: E. N. Zalta (Ed.). The Stanford Encyclopedia of Philosophy (Winter 2016 ed.). Recuperado de: https://plato.stanford.edu/archives/win2016/entries/lying-definition.

Margolis, J. (1962). "Lying Is Wrong” and "Lying Is Not Always Wrong”. Philosophy and Phenomenological Research, 23(1), 414-418.

McGonagle, T. (2017). 'Fake News': False Fears or Real Concerns. Netherlands 2uarterly of Human Rights, 35(4), 203-209. doi: 10.1177/0924051917738685 
McIntyre, L. (2018). Post-Truth. Cambridge: MIT Press.

Meibauer, J. (2005). Lying and Falsely Implicating. Journal of Pragmatics, 37(1), 1373-1399. doi: 10.1016/j.pragma.2004.12.007

Meibauer, J. (2011). On Lying: Intentionality, Implicature, and Imprecision. Intercultural Pragmatics, 8(1), 277-292. doi: 10.1515/iprg.2011.013

Meibauer, J. (2014). Lying at the Semantics-Pragmatics Interface. Boston-Berlin: Walter de Gruyter.

Oborne, P. (2005). The Rise of Political Lying. London: Simon \& Schuster.

Perelman, C., \& Oldbrechts-Tyteca L. (1969). The New Rhetoric. A Treatise on Argumentation. Notre Dame: University of Notre Dame Press.

Proctor, R. (2011). The Golden Holocaust. Berkeley: University of California Press.

Rabin-Havt, A. (2016). Lies Incorporated: The World of Post-Truth Politics. New York: Anchor Books.

Ramsey, M. (2000). Justifications for Lying in Politics. L. Cliffe, M. Ramsey, \& D. Bartlett (Eds.). The Politics of Lying. Implications for Democracy. LondonNew York: McMillan Press.

Redlawsk, D., Civettini A., \& Emmerson K. (2010). The Affective Tipping Point: Do Motivated Reasoners Ever 'Get It'? Political Psychology, 31(4), 563-593. doi: 10.1111/j.1467-9221.2010.00772.x

Rini, R. (2017). Fake News and Partisan Epistemology. Kennedy Institute of Ethics Journal, 27(2, Supplement), E43-E64.

Santos: 'El tal paro nacional agrario no existe'. (2013, agosto 25). Semana. Recuperado de: https://www.semana.com

Saul, J. (2012). Lying, Misleading, and What Is Said. Oxford: Oxford University Press.

Shapin, S. (1995). A Social History of Truth. Civility and Science in SeventeenthCentury England. Chicago: University of Chicago Press.

Simpson, D. (1992). Lying, Liars and Language. Philosophy and Phenomenological Research, 52(1), 623-639.

Sorensen, R., (2007). Bald-Faced Lies! Lying Without the Intent to Deceive. Pacific Philosophical Quarterly, 88(1), 251-264. doi: 10.1111/j.14680114.2007.00290.x 
Stanley, J. (2012, agosto 30). Speech, Lies, and Apathy. The New York Times. Recuperado de: http://opinionator.blogs.nytimes.com

Szabados, B., \& Soifer, E. (2004). Hypocrisy, Ethical Investigations. Toronto: Broadview Press.

Talisse, R. (2018, junio 9). There's No Such Thing As Fake News (and That's Bad News). 3: AM Magazine. Recuperado de: http://www.3ammagazine.com

Thomson, D. F. (1999). La ética política y el ejercicio de cargos públicos. Barcelona: Gedisa.

Trilling, L. (1971-1972). Sincerity and Authenticity, Cambridge: Harvard University Press.

Tullock, G. (1967). Toward a Mathematics of Politics. Ann Arbor: University of Michigan Press.

Waldron, J. (1999). Law and Disagreement. Oxford: Oxford University Press.

Williams, B. (2002). Truth and Truthfulness: An Essay in Genealogy. Princeton: Princeton University Press.

Williams, B. (2005). Truth, Politics, and Self-Deception. In the Beginning Was the Deed. Princeton: Princeton University Press. 